\title{
ANALISIS PENGARUH PRODUK, HARGA, TEMPAT, PROMOSI DAN E-QUALITY SERVICE TERHADAP KEPUTUSAN PEMBELIAN DI ZARA CENTRAL PARK PADA MASA PANDEMIC COVID-19
}

\author{
Kevin Daniel Thoby, Agus Wahyono \\ *) Dosen Tetap Program S1 Jurusan Manajemen Fakultas Ekonomi dan Bisnis \\ Universitas Satya Negara Indonesia. \\ Email: tobydragneel@gmail.com; agoeswahyono9@gmail.com
}

\begin{abstract}
This study aims to determine the effect of Promotion, Price, Location, Promotion, and E-service quality on purchasing decisions of Zara Central Park Mall partially or simultaneously. The data used are primary data collected through distributing questionnaires to 100 respondents who have visited and purchased at Zara Central Park Mall. The method used in this study is a quantitative method and the results of the study are based on respondents' answers using a Likert scale. The data analysis method used in this study is the Multiple Linear Regression Test, $F$ test, $t$ test and the coefficient of determination.

The results showed that simultaneously ( $F$ test) there was a significant influence between Product (X1), Price (X2), Location (X3) Promotion (X4), E-service quality (X5) variables on Purchasing Decisions (Y). Partially ( $t$ test) Product and Price have a significant effect on purchasing decisions, while Location, Promotion and E-service quality do not have a significant effect on purchasing
\end{abstract}

Keywords: Promotion, Price, Location, Promotion, E-service quality and Purchase Decision.

\section{PENDAHULUAN}

Dilansir dari situs CNBC Indonesia Sri Mulyani menjelaskan bahwa Dampak Covid19 pada kuartal II-2020 mengalami penurunan drastic. Aspek yang terkontraksi sangat dalam tampak pada sektor konsumsi yang tercatat minus 5,6\% dan investasi minus 8,6\%. Kemudian, ekspor minus $11,7 \%$ dan impor minus 17\%. WHO (World Healthy Organization) juga mengumumkan bahwa COVID-19 yang merupakan pandemi dunia juga meruba, perilaku konsumen di berbagai sektor bisnis. Kebijakan pembatasan sosial berskala besar (PSBB) yang mengakibatkan mobilitas masyarakat terhenti dan pergerakan perekonomian lumpuh sementara. Terlepas dari hal tersebut, maka pola konsumsi masyarakat yang tadinya sangat konsumtif tiba-tiba berkurang drastis karena adanya pembatasan tersebut, sehingga tidak sedikit perusahaan retail yang merubah strategi dalam pemasarannya guna mendorong konsumen untuk melakukan keputusan pembelian.

Industri ritel pakaian merupakan sektor yang paling terpukul selama pandemi. Pertumbuhannya diperkirakan hanya berkisar 1,5-1,6 persen pada 2020. Oleh karena itu, Inditex Group selaku perusahaan yang menaungi ZARA mengambil keputusan menutup hingga 1200 toko setelah mengumumkan kerugian di merek-merek lain, seperti Bershka, Pull \& Bear, dan Massimo Dutti di quartal pertama. Ketatnya Protocol kesehatan di masa pandemic Covid-19 ini mengubah Prilaku konsumen untuk pergi berbelanja ke swalayan, hal tersebut sangat berdampak pada penurunan keputusan pembelian di Zara . Banyak store yang masih beroprasi dapat beroprasi di masa New Normal ini, tapi tidak dapat menutupi penurunan pendapatan pada masing- masing store. Hal tersebut dapat kita lihat pada table yang tertera di bawah ini. Akan tetapi peneliti menemukan fakta baru, bahwa di tengah penurunan penjualan di masa Pandemic 
Covid-19 ini, sektor penjualan di bidang Online mengalami kenaikan yang cukup besar. Hal ini dapat kita lihat dari data komparasi perbandingan pendapatan online dan offline selama masa pandemic covid19 pada Grafik 1.1.

Grafik 1.1.

\section{Persentase Perbandingan Pendapatan Online dan Offline Zara Central Park Tahun 2019 -} 2020

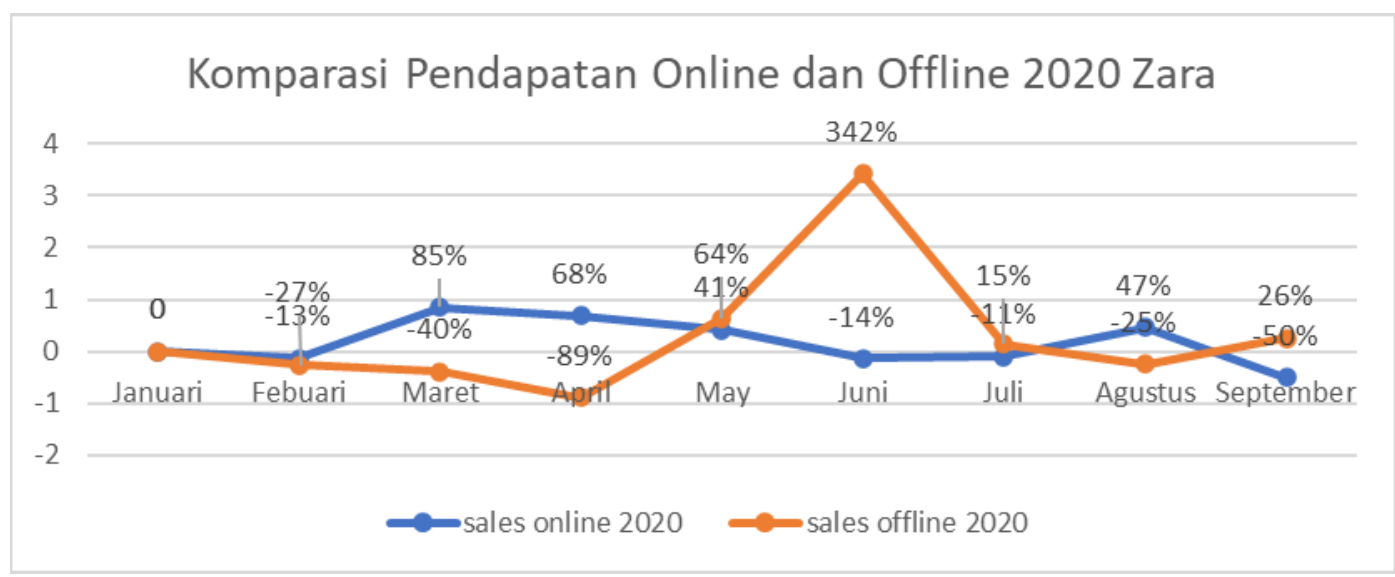

Grafik diatas menunjukkan bahwa penjualan Zara Central Park pada system Online pada masa pandemic tepatnya dari bulan maret sampai september mengalamai kenaikan penjualan yang cukup besar dibandingkan bulan Januari dan Febuari 2020 (sebelum Pandemi covid-19). Namun penjualan dengan sistem offline pendapatan Zara mengalami penurunan. Hal ini menunjukan prilaku konsumen yang berubah pada masa Pandemic ini.

Menurut Philip Kotler (2016) marketing mix adalah seperangkat alat pemasaran yang digunakan perusahaan untuk terus menerus mencapai tujuan pemasarannya di pasar sasaran. Konsep Marketing Mix terdiri dari products, price, promotions, place, people, process, dan physical evidence atau 7P (Booms \& Bitner (1982) sampai 15P Product/service, Price, Place, Promotion, People, Politics, Public Relations, Probe, Partition, Prioritize, Position, Profit, Plan, Performance, Positive Implementations Baumgartner (1991). Ditengah keterbatasan penerapan strategi Marketing Mix di masa Pandemic Covid-19 ini Zara juga mengembangkan strategi pemasaran melalui E-quality Service, hal tersebut dilakukan karena meningkatnya minat dan keputusan pembelian konsumen secara online. Upaya tersebut dilakukan untuk menutupi fenomena bahwa terjadi penurunan penjualan yang drastis Zara Central Park. Untuk itu perlu kajian apakah strategi pemasaran Mix Marketing dan E-Service Quality dapat membuka peluang penjualan lebh meningkat bahkan meningkatkan keputusan pembelian konsumen?

Konsep 4P (marketingmix) dalam penelitian yang dilakukan oleh peneliti seperti Bayu Trianto (2014) menyatakan bahwa produk mempengaruhi secara positif terhadap keputusan pembelian alat olahraga. Namun, Anggriawan (2017) menunjukan bahwan variabel produk, promosi, distribusi dan harga berpengaruh negatif signifikan namun secara berturut-turut variabel produk memiliki nilai pernyataan negatif tertinggi dari penjualan Toto. Penelitian Alfi Hoirjuga oh menyatakan bahwa variabel harga berpengaruh positif pada keputusan pembelian di Zara Central Park tahun (2019). Namun menurut Sweetly Jane Mongisidi, (2019) menyatakan bahwa Harga tidak berpengaruh signifikan terhadap Keputusan Pembelian sepatu Nike.

Utami (2010: 69) menyatakan pengaruh stimulus dan situasi yang terdapat di lingkungan Lokasi berbelanja merupakan penyebab terjadinya impulse buying dalam keputusan pembelian. 
Juga secara teori bahwa promosi merupakan salah satu variabel di dalam marketing mix (bauran pemasaran) yang penting dilaksanakan oleh perusahaan dalam pemasaran produk atau jasanya (Basu Swasta dan Irawan (1981). Disamping dengan 4P tersebut Zara melakukan strategi Equality Service. E-service quality adalah pelayanan berbasis elektronik yang digunakan untuk memfasilitasi belanja, pembelian maupun pengiriman produk dan jasa secara efektif dan efisien (Parasuraman and Malhotra, 2002). Dengan memaksimalkan strategi dibidang Equality Service ini zara dapat menutupi penurunan keputusan pembelian pada masa Pandemic Covid-19, karena dalam penelitian yang dilakukan oleh Edy Yulianto (2016), Equality Service berpengaruh signifikan terhadap Keputusan Pembelian di Tokopedia

Berdasarkan pada uraian latar belakang masalah di atas maka dapat diajukan sebuah penelitian dengan judul "Analisis Pengaruh Marketing MIX Dan Equality Service Terhadap Keputusan Pembelian Di Zara Central Park Pada Masa Pandemic Covid-19”.

\section{LANDASAN TEORI}

\section{Keputusan Pembelian}

Menurut Tjiptono dan Diana (2016:60) Keputusan Pembelian adalah tahap pra-pembelian yang mencangkup semua aktivitas konsumen-konsumen sebelum terjadinya transaksi pembelian dan pemakaian produk. Konsumen dalam memutuskan pembelian menurut Pride dan Ferrel dalam Sangadji (2013:335) membagi faktor yang mempengaruhi perilaku konsumen ke dalam tiga kelompok, yaitu pertama karena faktor pribadi (demografi, situasional, keterlibatan), kedua faktor Faktor Psikologis (Motif, Persepsi, Kemampuan dan Pengetahuan serta sikap) dan yang ketiga factor faktor Sosial (peran dan pengaruh keluarga, kelompok referensi, kelas sosial).

\section{Produk}

Definisi produk menurut Kotler dan Armstrong (2016) adalah sebagai berikut: Segala sesuatu yang dapat ditawarkan ke pasar untuk mendapat perhatian, dibeli, dipergunakan, atau dikonsumsi dan yang dapat memuaskan keinginan atau kebutuhan. Produk yang baik dan buruk dapat mempengaruhi daya beli konsumen karena menjadi dasar daya Tarik konsumen. Konsumen ketika akan membeli produk mempertimbangkan beberapa dimensi dan indikator yaitu atribut produk yang meliputi merek, kemasan, pemberian label, dan layanan pelengkap produk tersebut.

\section{Harga}

Menurut Kotler dan Keller (2016:483) Harga merupakan salah satu unsur bauran pemasaran yang menghasilkan pendapatan, unsur lainnya menghasilkan biaya. Harga juga mengkomunikasikan nilai posisi perusahaan terhadap produk atau mereknya. Produk yang dirancang dengan baik dan dipasarkan masih bisa menurut memberi harga premium dan menuai keuntngan besar. Dimensi Harga Menurut Kotler dan keller (2016:47) merupakan satu elemen bauran pemasaran yang menghasilkan pendapatan, sedangkan elemen lain menghasilkan biaya. Dimensi harga terdiri dari a) daftar harga adalah suatu uraian yang dicantumkan pada label atau produk. b) diskon atau potongan harga, pengurangan dari daftar harga. c) kredit, bentuk pembayaran dan pinjaman. d) eriode pembayaran, cicilan sesuai kesepakatan antara penjual dan pembeli yang berhubungan dengan kredit.

\section{Lokasi}

Lokasi merupakan tempat melayani konsumen, dapat pula diartikan sebagai tempat untuk memajangkan barang-barang dagangannya.Menurut Fandy Tjiptono (2014: 92) "Lokasi adalah tempat perusahaan beroperasi atau tempat perusahaan melakukan kegiatan untuk menghasilkan 
barang dan jasa yang mementingkan segi ekonominya." Menurut Ujang kotler merupakan tempat usaha yang sangat mempengaruhi keinginan seseorang konsumen untuk datang dan berbelanja". Faktor yang Dipertimbangkan dalam Pemilihan Lokasi
a. Aksesibilitas, yaitu kemudahan untuk dijangkau.
b. Visibilitas, yaitu kemudahan untuk dilihat.
c. Lalu lintas, dalam hal ini ada dua hal yang perlu diperhatikan:
d. Tempat parkir yang luas dan aman
e. Ekspansi, yaitu tersedianya tempat yang luas untuk perluasan di kemudian hari.
f. Lingkungan, yaitu daerah sekitar yang mendukung jasa/produk yang ditawarkan.
g. Persaingan, yaitu ada tidaknya pesaing sejenis di sekitar lokasi tersebut.
h. Peraturan pemerintah.

\section{Promosi}

Dalam pelaksanaan kegiatan promosi, manajemen tidak terlepas dari berbagai faktor yang mempengaruhinya dalam menentukan kombinasi yang terbaik dari variabel-variabel promotional mix. Faktor-faktor yang mempengaruhi dalam pelaksanaan promosi, yaitu: 1) Dana yang tersedia, 2) Sifat pasar, 3) Sifat produk, 4) Tahap dalam daur hidup produk.

Bauran promosi merupakan program komunikasi pemasaran total sebuah perusahaan yang terdiri dari iklan, penjualan pribadi, promosi penjualan, dan hubungan masyarakat yang dipergunakan perusahaan untuk mencapai tujuan iklan dan pemasarannya. Variabel-variabel yang ada di dalam promotional mix tersebut ada empat (ada juga yang berpendapat lebih dari empat variabel), yaitu: 1) Personal selling 2) Periklanan, 3) Promosi Penjualan, 4) Publisitas

\section{E-Service Quality}

Kualitas layanan pada lingkungan online menjadi sesuatu yang penting dalam penentuan kesuksesan atau kegagalan dari perdagangan elektronik. Voss (2003) mendefinisikan layanan dalam lingkungan elektronik (e-service) sebagai "the delivery as service using new media such as the web".

E-service quality memiliki variabel atau konstruk yang biasa disebut dengan dimensi eservqual. Adapun dimensi-dimensi dari e-servqual adalah sebagai berikut (Trisnawati \& Fahmi, 2017) : 1. Efisiensi, 2. Fullfilment, 3. System Availability, 4. Privasi 5. Responsiveness 6. Compensation 7. Contact. Pendapat lain yang dikutip oleh Kotler dan Keller (2017) intisari kualitas layanan yang dilebur menjadi lima dimensi yang dikenal sebagai ESERVQUAL, yaitu: 1) Reliability (kehandalan), 2) Responsiveness (ketanggapan), 3) Assurance (Jaminan), 4) Empathy (Empati), kesediaan memberikan perhatian yang mendalam dan khusus kepada masingmasing pelanggan. 5) Tangibles (Benda berwujud)

\section{Kerangka Pemikiran}

Kerangka pemikiran dalam penelitian ini berdasarkan pada fenomena, kajian teori dan rumusan masalah serta hasil penelitian terdahulu yang telah diuraikan diatas sebagai berikut: 


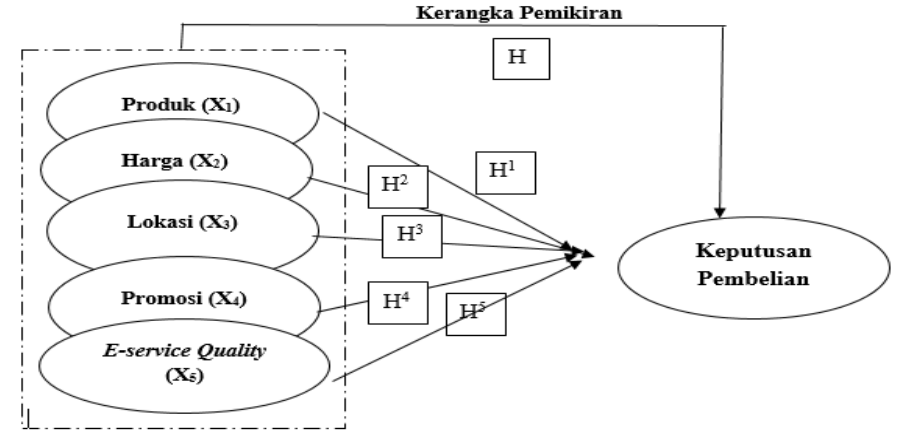

Gambar 1 Kerangka Pemikiran

Hipotesis yang digunakan dalam penelitian ini adalah:

$\mathrm{H}^{1}$ : Produk, Harga, Lokasi, Promosi dan Equlity Service Berpengaruh simultan terhadap Keputusan mbelian pada Store Zara pada masa pandemic covid-19.

$\mathrm{H}^{2}$ : Produk berpengaruh terhadap Keputusan Pembelian pada Store Zara pada masa pandemic covid-19.

$\mathrm{H}^{3}$ : Harga berpengaruh terhadap Keputusan Pembelian pada Store Zara pada masa pandemic covid-19.

$\mathrm{H}^{4}$ : Lokasi berpengaruh terhadap Keputusan Pembelian pada Store Zara pada masa pandemic covid-19.

$\mathrm{H}^{5}$ : Promosi berpengaruh terhadap Keputusan Pembelian pada Store Zara pada masa pandemic covid-19.

$\mathrm{H}^{6}$ : E-service Quality berpengaruh terhadap Keputusan Pembelian Store Zara pada masa pandemic covid-19.

\section{METODOLOGI PENELITIAN}

\section{Desain Penelitian}

Jenis penelitian yang dilakukan menggunakan penelitian kausal yang merupakan penelitian untuk mengetahui pengaruh antara satu atau lebih variabel bebas (independent variable) Produk, Harga, Lokasi, Promosi dan Equality Service terhadap variabel terikat (dependent Variable) Keputusan pembelian.

\section{Waktu dan Tempat Penlitian}

Penelitian ini dilaksanakan di ZARA Jakarta Barat pada bulan Oktober 2020 sampai Februari 2021.

\section{Populasi}

Populasi target adalah orang yang berkunjung pada Zara Central Park dan pernah membeli produk Zara. Sedangkan teknik sampling yang digunakan adalah teknik nonprobability sampling. Sementara Teknik pengambilan sampel dalam penelitian adalah dengan menggunakan Sampling Insidential yaitu teknik penentuan sampel berdasarkan kebetulan, yaitu siapa saja yang secara kebetulan/incidental bertemu dengan peneliti dapat digunakan sebagai sampel, bila dipandang orang yang kebetulan ditemui cocok sebagai sumber data dengan menggunakan Rumus Rosco. 


\section{HASIL ANALISIS DAN PEMBAHASAN}

\section{Analisis Deskriptif Pernyataan Kuesioner}

Tabel 1

\section{Output Statistik Deskriptif}

Descriptive Statistics
\begin{tabular}{|l|l|l|l|l|l|}
\hline & N & Minimum & Maximum & Mean & Std. Deviation \\
\hline TOTALY & 100 & 34 & 92 & 76.11 & 9.307 \\
TOTALX1 & 100 & 37 & 64 & 54.00 & 5.966 \\
TOTALX2 & 100 & 21 & 44 & 36.66 & 4.753 \\
TOTALX3 & 100 & 14 & 24 & 20.23 & 2.605 \\
TOTALX4 & 100 & 17 & 36 & 28.91 & 4.524 \\
TOTALX5 & 100 & 10 & 16 & 14.15 & 1.641 \\
Valid N (listwise) & 100 & & & & \\
\hline
\end{tabular}

Sumber: Data Diolah Peneliti 2021

- Keputusan pembelian memiliki nilai minimum 34, maximum 92, mean 76,11 dan standar deviasi 9,307 dalam hal ini jika mean 76,11 dibagi jumlah pernyataan 23 maka didapatkan hasil 3,30.

- Produk memiiki nilai minimum 37, maximum 64, mean 54,00 dan standar deviasi 5,966 dalam hal ini jika mean 54,00 dibagi jumlah pernyataan 16 maka didapatkan hasil 3,37.

- Harga memiliki nilai minimum 21, maximum 44, mean 36,66 dan standar deviasi 4,753 dalam hal ini jika mean 36,66 dibagi jumlah pernyataan 11 maka didapatkan hasil 3,33.

- Lokasi mempunyai nilai minimum 14, maximum 24, mean 20,23 dan standar deviasi 2,605 dalam hal ini jika mean 20,33 dibagi jumlah pernyataan 6 maka didapatkan hasil 3,38.

- Promosi mempunyai nilai minimum 17, maximum 36, mean 28,91 dan standar deviasi 4,524 dalam hal ini jika mean 28,91 dibagi jumlah pernyataan 9 maka didapatkan hasil 3,21.

- E-service Quality mempunyai nilai minimum 10, maximum 16, mean 14,15 dan standar deviasi 1,641 dalam hal ini jika mean 14,15 dibagi jumlah pernyataan 4 maka didapatkan hasil 3,53.

\section{Analisis Instrumen Penelitian}

\section{Uji Validitas dan Uji Realibilitas}

Uji validitas bertujuan untuk mengetahui seberapa valid atau sah tidaknya suatu item dalam pengukuran apa yang ingin diukur (kuesioner). Uji Realibilitas digunakan untuk mengetahui konsistensi alat ukur yang biasanya menggunakan kuesioner. Setelah melakukan uji instrument maka di hasilkan bahwa semua item valid dan reliabel. Duwi Priyatno (2014:64).

\section{Uji Asumsi Klasik}

\section{Uji Normalitas}

Hasil Uji normalitas pada model regresi digunakan untuk menguji apakah nilai residual yang dihasilkan dari regresi terdistribusi secara normal atau tidak. Duwi Priyanto (2014:90 


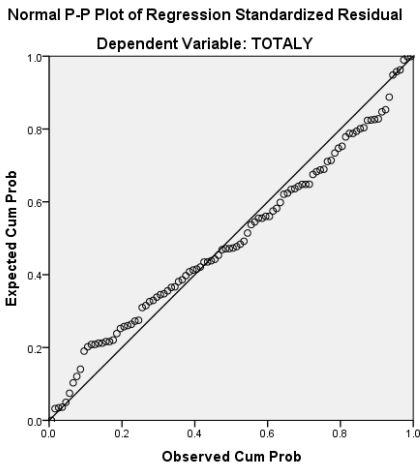

Gambar 1. Normalitas P Plot
One-Sample Kolmogorov-Smirnov Test

\begin{tabular}{ll|r|}
\hline & & $\begin{array}{r}\text { Unstandardized } \\
\text { Residual }\end{array}$ \\
\hline$N$ & 100 \\
Normal Parameters ${ }^{\mathrm{a}, \mathrm{b}}$ & Mean & .0000000 \\
& Std. Deviation & 5.48081413 \\
Most Extreme Differences & Absolute & .086 \\
& Positive & .086 \\
& Negative & -.068 \\
Test Statistic & .086 \\
Asymp. Sig. (2-tailed) & $.066^{c}$ \\
\hline a. Test distribution is Normal. \\
b. Calculated from data. \\
c. Lilliefors Significance Correction.
\end{tabular}

Tabel 2

Output Uji Normalitas Kolmogrov Smirnov

Sumber : Hasil olahan peneliti 2021

\section{Uji Heteroskedastisitas}

Heteroskedastisitas adalah varian yang tidak sama pada semua pengamatan didalam metode regresi. Menurut Duwi Priyatno (2014:99). Regresi yang baik seharusnya tidak terjadi heteroskeditisitas. Apabila menggunakan Uji Glejser, dapat dilihat dari sebaran data-data yang dikatakan bebas heteroskedastisitas/ tidak terjadi heteroskeastisitas adalah data yang tersebar/tidak berkumpul disatu titik.

\section{Gambar 2. Scaterploot}

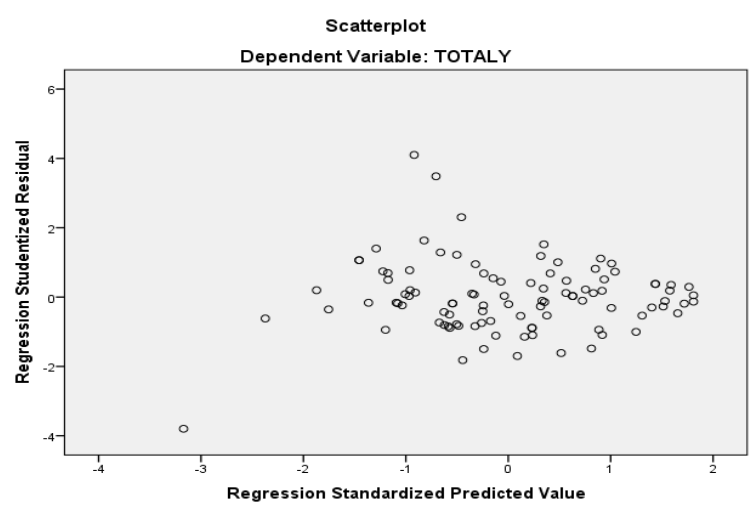

Sumber : Hasil olahan peneliti 2021

Dari output dapat diketahui bahwa titik-titik tidak membentuk pola yang jelas dan titik-titik menyebar diatas dan dibawah angka 0 pada sumbu Y. Jadi, dapat disimpulkan bahwa tidak terjadi heteroskedastisitas dalam model regresi.

\section{Uji Multikolinearitas}


Uji ini bertujuan untuk mengetahui apakah antara variabel bebas yang terdapat dalam model regresi memiliki hubungan linear yang sempurna atau mendekati sempurna Duwi Priyatno (2014:99

Tabel. 3

\section{Output Uji Multikolinearitas}

\begin{tabular}{|c|c|c|c|c|c|}
\hline \multicolumn{6}{|l|}{ Coefficients ${ }^{\mathrm{a}}$} \\
\hline \multirow{2}{*}{ Model } & \multicolumn{2}{|c|}{$\begin{array}{l}\text { Unstandardized } \\
\text { Coefficients }\end{array}$} & \multirow{2}{*}{$\begin{array}{l}\text { Standardized } \\
\text { Coefficients } \\
\text { Beta }\end{array}$} & \multicolumn{2}{|c|}{ Collinearity Statistics } \\
\hline & $\mathrm{B}$ & $\begin{array}{l}\text { Std. } \\
\text { Error }\end{array}$ & & Tolerance & VIF \\
\hline (Constant) & 7.978 & 5.968 & & & \\
\hline TOTALX1 & .741 & .150 & .475 & .400 & 2.502 \\
\hline TOTALX2 & .677 & .197 & .346 & .363 & 2.757 \\
\hline TOTALX3 & .138 & .263 & .039 & .682 & 1.466 \\
\hline TOTALX4 & .193 & .165 & .094 & .574 & 1.741 \\
\hline TOTALX5 & -.360 & .477 & -.063 & .521 & 1.921 \\
\hline
\end{tabular}

a. Dependent Variable: TOTALY

Sumber : Hasil olahan peneliti 2021

Berdasarkan tabel 2 dapat diketahui bahwa Produk $\left(X_{1}\right)$ mempunyai nilai tolerance 0,400 , Harga $\left(\mathrm{X}_{2}\right)$ mempunyai nilai tolerance 0,363 , Lokasi $\left(\mathrm{X}_{3}\right)$ mempunyai nilai tolerance 0,682 , Promosi $\left(\mathrm{X}_{4}\right)$ mempunyai nilai tolerance 0,574 , dan E-service quality $\left(\mathrm{X}_{5}\right)$ mempunyai nilai tolerance 0,521. Sedangkan Produk $\left(\mathrm{X}_{1}\right)$ mempunyai nilai VIF 2,502, Harga $\left(\mathrm{X}_{2}\right)$ mempunyai nilai VIF 2,757, Lokasi $\left(\mathrm{X}_{3}\right)$ mempunyai nilai VIF 1,466, Promosi $\left(\mathrm{X}_{4}\right)$ mempunyai nilai VIF 1,741, dan E-service quality $\left(\mathrm{X}_{5}\right)$ mempunyai nilai VIF 1,921. Maka dapat disimpulkan bahwa tidak terjadi multikolerasi antar variabel adalah lebih besar dari 0,10 dan nilai VIF (Variance Inflation Factory) untuk masing-masing variabel adalah lebih kecil dari 10.

\section{Uji Autokolerasi}

Autokorelasi merupakan kolerasi antara anggota observasi yang disusun menurut waktu dan tempat. Menurut Duwi Priyatno (2014:106). Menurut regresi yang baik seharusnya tidak terjadi autokolerasi. Metode pengujian menggunakan Uji Dubin Watson (DW test).

Tabel 4

Output Uji Autokolerasi

\begin{tabular}{|c|c|c|c|c|c|}
\hline \multicolumn{6}{|c|}{ Model Summary } \\
\hline Model & $\mathrm{R}$ & R Square & \begin{tabular}{|ll} 
Adjusted & $\mathrm{R}$ \\
Square & \\
\end{tabular} & $\begin{array}{l}\text { Std. Error of the } \\
\text { Estimate }\end{array}$ & Durbin-Watson \\
\hline 1 & $.872^{\mathrm{a}}$ & .760 & .747 & 4.739 & 2.048 \\
\hline
\end{tabular}

a. Predictors: (Constant), TOTALX5, TOTALX4, TOTALX2, TOTALX1, TOTALX3

b. Dependent Variable: TOTALY

Berdasarkan table 3 diatas, dapat diketahui bahwa nilai dari Durbin Watson dengan variabel bebas sebanyak 5 variabel adalah 2,048, dapat dipakainya rumus dari table Durbin Watsun dengan $\mathrm{k}=5$ yaitu $\mathrm{DU}=1,780$. Metode Metode pengujian menggunakan Uji Dubin Watson (DW 
test) dengan dasar pengambilan keputusan bahwa 1,780 $<2,048<2,219$ maka $\mathrm{H}_{\mathrm{o}}$ diterima artinya tidak terjadi autokolerasi.

\section{Uji Analisis Kolerasi}

Tabel 4

Output Uji Autokolerasi

\begin{tabular}{|c|c|c|c|c|c|c|c|}
\hline \multicolumn{8}{|c|}{ Correlations } \\
\hline & & TOTALY & TOTALX1 & TOTALX2 & TOTALX3 & TOTALX4 & TOTALX5 \\
\hline \multirow{3}{*}{ TOTALY } & $\begin{array}{l}\text { Pearson } \\
\text { Correlation }\end{array}$ & & $.848^{* *}$ & $.770^{* *}$ & $.606^{* *}$ & $.631^{4}$ & $.482^{*}$ \\
\hline & Sig. (2-tailed) & & .000 & .000 & .000 & .000 & .000 \\
\hline & $\mathrm{N}$ & 100 & 100 & 100 & 100 & 100 & 100 \\
\hline \multirow{3}{*}{ TOTALX1 } & $\begin{array}{l}\text { Pearson } \\
\text { Correlation }\end{array}$ & $.848^{* *}$ & & .771 & .716 & $.746^{* *}$ & $.595^{*}$ \\
\hline & Sig. (2-tailed) & .000 & & .000 & .000 & .000 & .000 \\
\hline & $N$ & 100 & 100 & 100 & 100 & 100 & 100 \\
\hline \multirow{3}{*}{ TOTALX2 } & $\begin{array}{l}\text { Pearson } \\
\text { Correlation }\end{array}$ & $.770^{* *}$ & .771 & & $.727^{* \star}$ & $.625^{\star *}$ & $.563^{* *}$ \\
\hline & Sig. (2-tailed) & .000 & .000 & & .000 & .000 & .000 \\
\hline & $\mathrm{N}$ & 100 & 100 & 100 & 100 & 100 & 100 \\
\hline \multirow{3}{*}{ TOTALX3 } & $\begin{array}{l}\text { Pearson } \\
\text { Correlation }\end{array}$ & $.606^{* *}$ & $.716^{*}$ & $.727^{* *}$ & & $.693^{* *}$ & $.910^{*}$ \\
\hline & Sig. (2-tailed) & .000 & .000 & .000 & & .000 & .000 \\
\hline & $\mathrm{N}$ & 100 & 100 & 100 & 100 & 100 & 100 \\
\hline \multirow{3}{*}{ TOTALX4 } & $\begin{array}{l}\text { Pearson } \\
\text { Correlation }\end{array}$ & $.631^{1}$ & $.746^{* *}$ & $.625^{*}$ & $.693^{*+}$ & & $.477^{*}$ \\
\hline & Sig. (2-tailed) & .000 & .000 & .000 & .000 & & .000 \\
\hline & $\mathrm{N}$ & 100 & 100 & 100 & 100 & 100 & 100 \\
\hline \multirow{3}{*}{ TOTALX5 } & $\begin{array}{l}\text { Pearson } \\
\text { Correlation }\end{array}$ & $.482^{* 4}$ & $.595^{\star \star}$ & $.563^{* *}$ & $.910^{*}$ & $.477^{*+}$ & \\
\hline & Sig. (2-tailed) & .000 & .000 & .000 & .000 & .000 & \\
\hline & $\mathrm{N}$ & 100 & 100 & 100 & 100 & 100 & 100 \\
\hline
\end{tabular}

Sumber : Hasil olahan peneliti 2021

1) Korelasi Produk terhadap Keputusan Pembelian. Diketahui bahwa korelasi antara variabel Produk terhadap Keputusan Pembelian. $r=0,848$, hal ini menunjukkan bahwa hubungan positif atau searah yang sangat kuat.

2) Korelasi Harga terhadap keputusan pembelian. Diketahui bahwa korelasi antara variabel Harga terhadap Keputusan Pembelian. $r=0,770$, hal ini menunjukkan bahwa hubungan positif atau searah yang kuat.

3) Korelasi Lokasi terhadap Keputusan Pembelian. Diketahui bahwa korelasi antara variabel Lokasi terhadap Keputusan Pembelian. $r=0,606$, hal ini menunjukkan bahwa hubungan positif atau searah yang kuat.

4) Korelasi Promosi terhadap Keputusan Pembelian. Diketahui bahwa korelasi antara variabel promosi terhadap Keputusan Pembelian. $r=0,631$, hal ini menunjukkan bahwa hubungan positif atau searah yang kuat.

5) Korelasi E-service quality terhadap Keputusan Pembelian. Diketahui bahwa korelasi antara variabel E-service quality terhadap Keputusan Pembelian. $\mathrm{r}=0,482$, hal ini menunjukkan bahwa hubungan positif atau searah yang sedang.

\section{Uji Hipotesis}

\section{Uji Regresi Linier Berganda}


Tabel 5

Output Uji Regresi Linier Berganda

\begin{tabular}{|c|c|c|c|c|c|}
\hline \multicolumn{6}{|c|}{ Coefficients $^{a}$} \\
\hline \multirow[t]{2}{*}{ Model } & \multicolumn{2}{|c|}{$\begin{array}{c}\text { Unstandardized } \\
\text { Coefficients }\end{array}$} & \multirow{2}{*}{$\begin{array}{c}\begin{array}{c}\text { Standardiz } \\
\text { ed } \\
\text { Coefficient } \\
\text { s }\end{array} \\
\text { Beta }\end{array}$} & \multirow[t]{2}{*}{$\mathbf{t}$} & \multirow[t]{2}{*}{ Sig. } \\
\hline & B & Std. Error & & & \\
\hline \multirow{6}{*}{$\begin{array}{l}\text { (COnstant) } \\
\text { TOTAL } \times 1 \\
\text { TOTAL } \times 2 \\
\text { TOTAL } \times 3 \\
\text { TOTAL } \times 4 \\
\text { TOTAL } \times 5\end{array}$} & 11.348 & 4.285 & & 2.649 & .009 \\
\hline & .947 & .138 & .670 & 6.851 & .000 \\
\hline & .664 & .176 & .347 & 3.769 & .000 \\
\hline & -.633 & .753 & -.166 & -.840 & .403 \\
\hline & .031 & .204 & .014 & .153 & .879 \\
\hline & .183 & .853 & .033 & .214 & .831 \\
\hline
\end{tabular}

Sumber : Hasil olahan peneliti 2021

Persamaan regresi dari Outpot SPSS diatas adalah sebagai berikut :

$$
Y=11,348+0,947 X 1+0,664 X 2-0,633 X 3+0,032 X 4+0,183 X 5
$$

Berdasarkan persamaan regresi diatas maka dapat disimpulkan:

1) Nilai konstanta sebesar 11,348 yang berarti jika variabel Produk $\left(X_{1}\right)$,Harga $\left(X_{2}\right)$, Lokasi $\left(\mathrm{X}_{3}\right)$, Promosi $\left(\mathrm{X}_{4}\right)$, dan E-service quality $\left(\mathrm{X}_{5}\right)$ bernilai 0 maka keputusan pembelian $(\mathrm{Y})$ bernilai 11,384 .

2) Nilai koefisien regresi variabel Produk $\left(X_{1}\right)$ sebesar 0,947 bernilai positif mempunyai arti bahwa jika regresi terhadap Produk $\left(\mathrm{X}_{1}\right)$ semakin baik, maka keputusan pembelian meningkat.

3) Nilai koefisien regresi variabel Harga $\left(\mathrm{X}_{2}\right)$ sebesar 0,664 bernilai positif mempunyai arti bahwa jika regresi terhadap Harga $\left(\mathrm{X}_{2}\right)$ semakin baik, maka keputusan pembelian meningkat.

4) Nilai koefisien regresi Lokasi $\left(\mathrm{X}_{3}\right)$ sebesar $-0,633$ bernilai negatif mempunyai arti bahwa walaupun regresi terhadap Lokasi $\left(\mathrm{X}_{3}\right)$ semakin baik, tetap tidak meningkatkan keputusan pembelian.

5) Nilai koefisien regresi variabel Promosi $\left(\mathrm{X}_{4}\right)$ sebesar 0,032 bernilai positif mempunyai arti bahwa jika regresi terhadap Promosi $\left(\mathrm{X}_{2}\right)$ semakin baik, maka keputusan pembelian meningkat.

6) Nilai koefisien regresi variabel E-service quality $\left(\mathrm{X}_{5}\right)$ sebesar 0,183 bernilai positif mempunyai arti bahwa jika regresi terhadap E-service quality $\left(\mathrm{X}_{5}\right)$ semakin baik, maka keputusan pembelian meningkat.

\section{Uji F (Uji Simultan)}

Tabel 6

Output Uji F (Uji Simultan)

ANOVA $^{\mathrm{a}}$

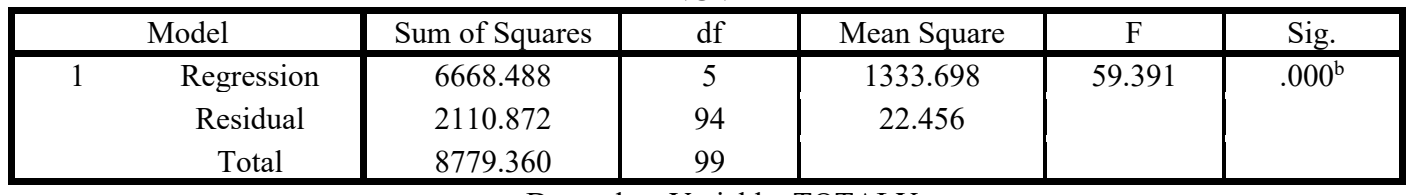

a. Dependent Variable: TOTALY

b. Predictors: (Constant), TOTALX5, TOTALX4, TOTALX2, TOTALX1, TOTALX3 
Berdasarkan tabel 4.18 dapat diketahui nilai $\mathrm{F}_{\text {hitung }}$ sebesar 59,39 dan $\mathrm{F}_{\text {tabel }}$ 2,31 dengan nilai signifikan yang diperoleh 0.000 berarti lebih kecil dari tingkat signifikansi 0,05 . Oleh karena itu nilai $\mathrm{F}_{\text {hitung }}>\mathrm{F}_{\text {tabel }}$ dan nilai sig $<0,05$ maka $\mathrm{H}_{0}$ ditolak dan Ha diterima.sehingga dapat disimpulkan bahwa Produk $\left(\mathrm{X}_{1}\right)$, Harga $\left(\mathrm{X}_{2}\right)$, Lokasi $\left(\mathrm{X}_{3}\right)$, Promosi $\left(\mathrm{X}_{4}\right)$, dan E-service quality $\left(\mathrm{X}_{5}\right)$ secara simultan berpengaruh terhadap keputusan pembelian $(\mathrm{Y})$.

\section{Uji t (Uji Parsial)}

Berdasarkan perhitungan pada tabel 5 dapat diuraikan hasil pengujian hipotesis parsial sebagai berikut:

1) Variabel Produk mempunyai nilai $t_{\text {hitung }} 6,851>t_{\text {tabel }} 1,985$ dengan nilai signifikansi 0,000 $<0,05$ sehingga $\mathrm{H}_{0}$ ditolak Ha diterima, berarti Produk terdapat pengaruh signifikan terhadap keputusan pembelian.

2) Variabel Harga mempunyai nilai $t_{\text {hitung }} 3,769>t_{\text {tabel }} 1,985$ dengan nilai signifikansi 0,000 $<0,05$ sehingga $\mathrm{H}_{0}$ ditolak Ha diterima, berarti Harga terdapat pengaruh signifikan terhadap keputusan pembelian.

3) Variabel Lokasi mempunyai nilai $t_{\text {hitung }} 0,840<t_{\text {tabel }} 1,984$ dengan nilai signifikansi 0,403 $>0,05$ sehingga $\mathrm{H}_{0}$ diterima Ha diterima, berarti Lokasi tidak berpengaruh terhadap keputusan pembelian.

4) Variabel Promosi mempunyai nilai $t_{\text {hitung }} 0,153<t_{\text {tabel }} 1,984$ dengan nilai signifikansi $0,879>0,05$ sehingga $\mathrm{H}_{0}$ diterima Ha diterima, berarti Promosi tidak berpengaruh terhadap keputusan pembelian.

5) Variabel E-service quality mempunyai nilai $t_{\text {hitung }} 0,214<t_{\text {tabel }} 1,984$ dengan nilai signifikansi 0,831 >0,05 sehingga $\mathrm{H}_{0}$ diterima $\mathrm{Ha}$ diterima, berarti E-service quality tidak berpengaruh terhadap keputusan pembelian.

\section{Uji $\mathbf{R}^{2}$ (Koefisien Determinasi)}

\section{Tabel 7}

Output Analisis Koefisien Determinasi $\left(\mathbf{R}^{2}\right)$

\begin{tabular}{|c|c|c|c|c|c|}
\hline Model & $\mathrm{R}$ & R Square & $\begin{array}{ll}\text { Adjusted } & \text { R } \\
\text { Square } & \end{array}$ & $\begin{array}{l}\text { Std. Error of the } \\
\text { Estimate }\end{array}$ & Durbin-Watson \\
\hline 1 & $.872^{\mathrm{a}}$ & .760 & .747 & 4.739 & 2.048 \\
\hline
\end{tabular}

a. Predictors: (Constant), TOTALX5, TOTALX4, TOTALX2, TOTALX1, TOTALX3

b. Dependent Variable: TOTALY

Dalam penelitian ini Produk $\left(\mathrm{X}_{1}\right)$, Harga $\left(\mathrm{X}_{2}\right)$, Lokasi $\left(\mathrm{X}_{3}\right)$, Promosi $\left(\mathrm{X}_{4}\right)$, dan E-service quality $\left(\mathrm{X}_{5}\right)$ berpengaruh sebesar $74,7 \%$ terhadap keputusan pembelian $(\mathrm{Y})$ dan sisanya sebesar $(100 \%-74,7 \%=25,3 \%)$ dipengaruhi oleh variabel lain yang tidak dijelaskan dalam penelitian ini.

\section{KESIMPULAN DAN SARAN}

\section{Kesimpulan}

Dari hasil analisis yang dilakukan mengenai Promosi, Harga, Lokasi, Promosi, dan E-service quality terhadap keputusan pembelian, terdapat kesimpulan yang dapat ditarik dari penelitian ini, sebagai berikut: 
1) Secara simultan terdapat pengaruh yang signifikan antara Promosi, Harga, Lokasi, Promosi, dan E-service quality terhadap pada Zara Central Park terhadap keputusan pembelian.

2) Terdapat pengaruh yang signifikan antara Produk pada Zara Central Park terhadap keputusan pembelian.

3) Terdapat pengaruh yang signifikan antara variable Harga pada Zara Central Park terhadap keputusan Secara

4) Tidak terdapat pengaruh antara variabel Lokasi pada Zara Central Park terhadap keputusan pembelian Secara parsial

5) Tidak terdapat pengaruh antara variabel Promosi pada Zara Central Park terhadap keputusan pembelian Secara parsial

6) Tidak terdapat pengaruh antara variabel E-service quality pada Zara Central Park terhadap keputusan pembelian Saran

\section{DAFTAR PUSTAKA}

Amstrong, Gerry dan Kottler, Philip. 2001. Prinsip-prinsip Pemasaran jilid I. Edisi kedelapan. Erlangga. Jakarta.

Amstrong, Gerry dan Kottler, Philip. 2008. Prinsip- Prinsip Pemasaran jilid I. Edisi kedua belas. Erlangga. Jakarta.

Basu Swasta dan Irawan. 1981. Manajemen Pemasaran Modern. Liberty. Yogyakarta.

Fandy Tjiptono. 2015. Strategi Pemasaran. Edisi 4: Andi.

Fandy Tjiptono \& Anastasia Diana. 2016. Pemasaran Esesi dan Aplikasi, Andi Offset, Yogyakarta.

Hurriyati, Ratih. (2015). Bauran Pemasaran dan Loyalitas Konsumen.Bandung: ALFABETHA.

Kotler, Keller. (2016). Marketing management. 15e, Boston, Pearson Education.

Kotler, Philip and Gary Amstrong. (2016). Prinsip-prinsip Pemasaran. Edisi13. Jilid 1. Jakarta:Erlangga.

Kotler, Philip \&amp; Keller, Kevin Lane. 2016. Manajemen Pemasaran Edisi 15. Jakarta: Erlangga.

Management Association, Information Resources. 2015. Web-Based Services: Concepts, Methodologies, Tools, and Applications. Volume 4, (USA).

Mullins, John W dan Walker Jr, Orville C. 2013. Marketing Management: A Strategic DecisionMaking Approach, 8th Edition, McGraw-Hill 151. International Edition.

Tjiptono, Fandy. 2014, Pemasaran Jasa - Prinsip, Penerapan, dan Penelitian, Andi Offset, Yogyakarta.

Dede Aprisal. 2017. Pengaruh Kualitas Produk, Harga, Promosi dan Lokasi Terhadap Keputusan Pembelian pada Great Store Clothing Samarinda.

http://ejournal.adbisnis.fisipunmul.ac.id/site/wpcontent/uploads/2017/08/Jurnal

https://opini.harianjogja.com/read/2020/05/12/543/1038906/opini-strategi-pemasaran-di-eracovid-19

https://www.uii.ac.id/strategi-pemasaran-digital-dalam-masa-wabah-covid-19/

https://kliksumut.com/strategi-pemasaran-4-0-ditengah-pandemi-covid-19/

http://lib.ui.ac.id/ 